\title{
Gated Field-Emission Cathode Radio-Frequency (RF) Gun
}

\section{Cooperative Research and Development Agreement Final Report}

\section{CRADA Number: FRA-2013-0006}

\section{Fermilab Technical Contact: Charles Thangaraj}

Summary Report

29 November 2016 


\section{NOTICE}

This report was prepared as an account of work sponsored by an agency of the United States government. Neither the United States government nor any agency thereof, nor any of their employees, makes any warranty, express or implied, or assumes any legal liability or responsibility for the accuracy, completeness, or usefulness of any information, apparatus, product, or process disclosed, or represents that its use would not infringe privately owned rights. Reference herein to any specific commercial product, process, or service by trade name, trademark, manufacturer, or otherwise does not necessarily constitute or imply its endorsement, recommendation, or favoring by the United States government or any agency thereof. The views and opinions of authors expressed herein do not necessarily state or reflect those of the United States government or any agency thereof.

Available electronically at http://www.osti.gov/bridge

Available for a processing fee to U.S. Department of Energy and its contractors, in paper, from:

U.S. Department of Energy Office of Scientific and Technical Information

P.O. Box 62

Oak Ridge, TN 37831-0062

phone: 865.576 .8401

fax: 865.576 .5728

email: mailto:reports@adonis.osti.gov

Available for sale to the public, in paper, from:

U.S. Department of Commerce

National Technical Information Service

5285 Port Royal Road

Springfield, VA 22161

phone: 800.553 .6847

fax: 703.605.6900

email: orders@ntis.fedworld.gov

online ordering: http://www.ntis.gov/ordering.htm 
In accordance with Requirements set forth in Article $X$ of the CRADA document, this document is the final CRADA report, including a list of Subject Inventions, to be forwarded to the Office of Science and Technical Information as part of the commitment to the public to demonstrate results of federally funded research.

CRADA number: $\quad$ FRA-2013-0006

CRADA Title: $\quad$ Gated Field-Emission Cathode Radio-Frequency (RF) Gun

Parties to the Agreement: RadiaBeam, LLC and Fermi Research Alliance, LLC

\section{Abstract of CRADA work:}

The goal of this CRADA was to procure the carbon nanotube cathode from Radiabeam, install it in HBESL and make current measurements as a function of the gun gradient. The gun was operated at $1.3 \mathrm{GHz}$. After testing, send the cathode back to RadiaBeam for surface analysis.

Prof. Piot (NIU/Fermilab), Dr. Daniel Mihalcea (NIU), Harsha Panuganti (NIU Ph.D student) and Jayakar Thangaraj (Fermilab) led the experimental efforts at HBESL.

\section{Summary of Research Results:}

All the above mentioned objectives have been reached.

For science results see the following peer-reviewed articles.

\section{Ampère-Class Pulsed Field Emission from Carbon-Nanotube Cathodes in a Radiofrequency}

\section{Resonator}

D. Mihalcea, L. Faillace, J. Hartzell, H. Panuganti, S. M. Boucher, A. Murokh, P. Piot, J. C. T. Thangaraj, Appl. Phys. Lett. 107, 033502 (2015).

"Simulations of Field-Emission Electron Beams from CNT Cathodes in RF Photoinjectors" Daniel Mihalcea (NIU, DeKalb) , Luigi Faillace (RadiaBeam Tech.) , Harsha Panuganti (NIU, DeKalb) , Jayakar C.T. Thangaraj (Fermilab) , Philippe Piot (Fermilab \& NIU, DeKalb), published in the Proceedings of the 6th International Particle Accelerator Conference (IPAC 2015) : Richmond, Virginia, USA, May 3-8, 2015, and available at https://jacowfs.jlab.org/conf/proceedings/IPAC2015/papers/wepje019.pdf 
Subject Inventions listing:

None

Report Date: 11/29/2016

Technical Contact at Fermilab: Charles Thangaraj

This document contains NO confidential, protectable or proprietary information. 